DOI: $10.17805 /$ zpu.2019.1.12

\title{
Свобода как феномен европейской истории и ее современная апология
}

\author{
М. И. КоЗьяКОВА
}

ВЫСШЕЕ ТЕАТРАЛЬНОЕ УЧИЛИЩЕ ИМ. М. С. ЩЕПКИНА

Среди универсальных ценностей человеческого бытия, сохраняющих актуальность проблематики в современном быстро меняющемся мире, особое место занимает феномен свободы. В статье анализируется феномен европейской свободы, рассматриваются его основания, эволюция, трансформации, которые претерпевает свобода в различные периоды европейской истории. Показано, что на всем протяжении истории свобода неизменно сопровождает человечество: многоликая и многогранная свобода является одним из важнейших онтологических оснований антропогенеза. Ее семантика варьируется в зависимости от ракурса рассмотрения, предлагая в словарях и энциклопедиях различные дефиниции. Личная независимость или осознанная необходимость; отсутствие гнета и угнетения; возможность выбора; самоволие и самостийность; политико-правовая автономия, оформленная законом или закрепленная традицией, - все эти определения характеризуют ее разнообразные смыслы, принадлежа одному и тому же референтному полю. Очевидно, в той или иной степени в анализе должны быть задействованы все семантические коды. В статье прослеживается процесс формирования самого феномена свободы в смысле, привычном современному обществу, где свобода понимается как в политическом смысле, так и в духовном, будучи опосредованной кантовской телеологией. Автор показывает, что процесс формирования такого феномена, как свобода, достаточно сложен, а история развития - длительна. В современном понимании понятие свободы оформилось в границах классической эпохи, эпохи Просвещения и было впервые сформулировано в Декларации прав человека и гражданина.

Ключевые слова: свобода; Декларация прав человека и гражданина; Просвещение; история Европы; Запад; история Запада

\section{ВВЕАЕНИЕ}

$\mathrm{B}$ современных условиях понятие свободы используется в крайне политизированном смысле, становится концептом и лозунгом в идейном, идеологическом противопоставлении западной и российской систем. При этом западные политологи, как правило, соотносят именно свою цивилизационную, историческую специфику с понятием «свобода», понимая ее в собственной, достаточно произвольной интерпретации, характеризуя при этом российские реалии как тотально «несвободные», авторитарные, дискриминационные. Так ли это? Аанный вопрос актуализирован не только в телевизионных ток-шоу, в выступлениях различных партийных функционеров нашей страны, но и на бытовом уровне, обсуждается в молодежной, в том числе в студенческой, среде. 
В культурной антропологии свобода представляет собой образцы жизненных практик, соответствующих тем или иным историческим условиям, модели возможностей, как укорененных в данном обиходе, так и возникающих в условиях новаций. Неповторимый облик свободы запечатлен в культуре каждой эпохи. Свобода, рассматриваемая в широком философском контексте, всегда имеет два аспекта: «свобода от» (от всевластия сил природы, бедствий, нищеты, эксплуатации; сословного, классового, иного социального и национального гнета) и «свобода для» (для творчества, наслаждения жизнью, развития личности и т. п.). Различение негативной и позитивной свободы имеет долгую традицию, отметив своим явным или неявным влиянием различные философские направления и школы начиная с Августина Блаженного, она присутствует у Ф. Шеллинга, Э. Фромма и др., содержится и в марксистской теории.

Подобная дихотомия рефлексируется более всего в онтологических абстракциях, но не в реальности бытия: в самой жизненной эмпирике абстрактной свободы не существует. Свобода здесь всегда атрибутивна, конкретна и относительна. В реальной жизненной стихии обе стороны представлены слитно: она сама является границей, отделяющей пространство возможностей от окружающего его пространства «несвободы» - мира природной и социальной зависимости. В культурологическом концепте в связи с проблематизацией феномена свободы можно выделить три вектора взаимодействий и, соответственно, три сферы осуществления свободы. Это свобода по отношению к природе, свобода по отношению к другому человеку (группе, сословию, классу, а также к самому себе), по отношению к Богу. Эту триаду можно определить как практическую, внешнюю свободу, реализуемую в коллективной деятельности людей. Свобода может концептуализироваться и как внутренний аспект, имеющий или не имеющий внешних выходов. Интеллектуальная, эмоциональная, творческая свобода, обладающая собственным потенциалом, может осуществляться имплицитно. Здесь она соприкасается со сферой ментального и в меньшей степени поддается верификации.

Каждую из трех сфер в отдельности, а также их конфигурации, появившиеся в ходе исторического развития, отличают те или иные особенности, свойства, характерные черты. В их совокупности, однако, имеется и нечто общее, присущее этим отношениям вне зависимости от их временно́й или культурной локализации. Отношение человека к природе, его свобода в этой сфере зависят от развития производительных сил, от познания законов природы, создающих возможности (способности) ее использования, от этических взглядов на допустимость подобной деятельности, принятых в обществе. По отношению к другому человеку (группам людей) возможные проявления свободы предполагают необходимость самоограничения и, как правило, жестко регламентируются общественными нормами, отражающими интересы и потребности коллектива, призванными обеспечить его благополучие и дальнейшее развитие. Основные параметры и цели при этом задаются «верхами», которые монополизируют собственное положение, закрепляя за собой максимально доступную степень свободы. В такой ситуации личная свобода определяется местом, занимаемым тем или иным лицом во властных структурах, властными полномочиями, а также этическими, религиозными критериями. Отношение к Богу, богам, к мистическому опыту при любых условиях имеет дело с трансценденцией, но отличается большой вариативностью при переживании этого опыта: свобода может полностью изгоняться из данной сферы или, наоборот, мыслиться как абсолютная; она может быть коллективным достоянием или являться сугубо личной интенцией. 
На ранних этапах общественного развития у разных культур наблюдаются общие закономерности. Пространство свободы при этом чрезвычайно ограничено, так как простая неспециализированная деятельность людей подчинена главной цели - выживанию кровнородственного коллектива в борьбе с природой и с соседями. Поскольку человек еще не выделился из природной среды, он одушевляет и персонифицирует окружающий его мир, слабо воспринимая различия между социальными и природными явлениями. Миф и магия, тотем и табу формируют первобытную картину мира, обслуживают устную традицию и коллективную память общества, исключительно скупо отмеряя свободу как коррелят природной данности. «Первые выделившиеся из животного царства люди были во всем существенном так же несвободны, как и сами животные; но каждый шаг вперед по пути культуры был шагом к свободе» (Энгельс, 1961: 116).

\section{СВОБОАА КАК ПОАИТИЧЕСКАЯ КАТЕГОРИЯ: АНТИЧНОСТЬ}

Особым образом структурируется свобода в Античности, наиболее резко и грубо разводя по разным полюсам жизненные начала рабства и свободы. Каждое из них при этом определяется реальностью и бытием своей антитезы (Иотман, 2000: 130) «Основным началом демократического строя является свобода», - утверждал Аристотель (Аристотель, 1983: 570). Греческий полис представлял уникальную для Аревнего мира, четко оформленную модель гражданских свобод, утвердившую классический тип античной демократии (свободу слова, равенство перед законом и в занятии должностей). Параллельно с оформлением гражданских свобод с культурным расцветом в V-IV вв. до н. э. складывается противоположная универсалия - система классического рабства. Понятия «раб» и «варвар» отождествляются, формируется эллинский «национализм».

То же самое происходило в республиканский период в Риме - расширение пространства свободы на одном полюсе знаменовало усиление рабства на другом. Борьба плебеев за патрицианские свободы завершилась победой, они вошли в состав «римского народа»: был веден институт народных трибунов, отменено кабальное рабство для римских граждан и членов их семей, плебисциты получили силу законов. Столетия победоносных республиканских войн обеспечили приток богатств и дешевой рабочей силы. Свободное самоуправление народа, республиканские учреждения и сенат, народные собрания и трибуны - на одном полюсе, и рабство, не имевшее аналогов по своим гигантским масштабам, - на другом - вот одно из противоречий римской Античности, достигшее особой остроты.

Само существование полиса делается в конечном счете возможным дишь благодаря труду рабов. Исключив в известной мере тяжелый физический труд и вообще труд, цель которого - зарабатывание на жизнь, эллинские и римские граждане освободились для более высоких занятий: искусством, спортом, политикой, интеллектуальной деятельностью. Но так ди был свободен свободный грек? Поставим этот вопрос вслед за парадоксальной формулировкой А. Шопенгауэра «Свободен ли тот, кто свободен?» Проявлялся ли в реальной жизни античный индивидуализм, то самое личностное начало, о котором можно судить по агональности греческой культуры, по искусству и философии, по именам скульпторов и художников, государственных деятелей и философов, запечатленных в истории? Был ли свободен субъект иной, родственной культуры, гражданин Вечного города?

Греческая свобода элиминирована социентарным фундаментом античного мироустройства. Быть гражданином - значило принадлежать к гражданской общине, 
к полису, к цивитас. Свобода мыслилась как высшая, сакральная ценность, требовавшая неизменного подчинения личных интересов общественным. Идея служения своим согражданам, полису, его богам представлялась главным предназначением человека, формировала античный идеал счастливой жизни. Счастье - это доблести и добродетели гражданского толка: семья и дети (прекрасные и благородные сыновья), достаток, благочестие, уважение сограждан, славная кончина на поле боя и, конечно, благодарность людей, посмертные почести, воздаваемые народом.

Еще более глубоко были укоренены коллективистские начала в римской культуре: организованность, дисциплина, правосознание стали структурообразующими основами общественного устройства, превратились в важнейшую традицию. Автономии личности не существовало, индивидуум растворялся в жизни коллектива: в совместном ратном труде, совместных решениях народных собраний, в общности религиозного культа. И греческая, и римская община жестко контролировали своих членов: любая независимость осуждалась, любой индивид, противопоставивший себя коллективу, был вне закона. Свобода в искусстве, философии, религии была под подозрением. Осужден и казнен был Сократ; умер в тюрьме Фидий; Перикл последние годы жизни находился под следствием. Аейственной мерой контроля за личностью была практика остракизма, используемая в политической борьбе. Изгнанию подверглись даже такие деятели, как политик Аристид или полководец Фемистокл, победитель персов в морском бою при о. Саламине.

Не предоставляют смертному человеку свободный выбор и бессмертные боги. Неотвратимость судьбы, идею рока как верховного закона природы воплощают мойры (парки), прядущие нить судеб. Поиски отсутствующей свободы, жажда обретения независимости нашли отражение в богоборческих тенденциях, противостоянии року, воплощающему волю богов. Это запечатлено в мифах (хрестоматийный пример Прометей), в греческих трагедиях и особенно в философии (яркий образец - стоицизм). Они, однако, составили узкую сферу творческой, философской, интеллектуальной рефлексии, не влияя на пространство свободы практической сферы.

Показательно, что уважение к чужой жизни не свойственно Античности: только гражданин, будучи господином, мог претендовать на статус «человека», остальные бесправная часть человечества, варвары и дикари. Их страдания и смерть воспринимались обывателем как нечто совершенно естественное. Об этом свидетельствует пыточная практика допроса «тел», принятая в Афинах, традиции римских гладиаторских игр, любимых как властью, так и народом. Все, в том числе интеллектуальная элита, рассматривали бои не только как развлечение, но и как «лучший урок мужества против боли и смерти» (Цицерон).

Рабство создало империю, и оно же стало ее могильщиком - в последние столетия своего существования римский мир как внешне, так и внутренне варваризируется. О поддержке населением варваров говорится, в частности, в трактате монаха Сальвиана (V в.): они идут искать у варваров римской человечности, спасаясь от варварской бесчеловечности римлян, «желают быть свободными в обличье рабов, а не рабами в обличье свободных» (цит. по: Ае Гофф, 1992: 15). Границы, отделявшие свободу от рабства, размываются как течением внутренних процессов, так и волнами варварских нашествий, приносящих иной социальный опыт, чуждые римлянам племенные законы и нормы. Наконец, остатки античной свободы исчезают вместе с остатками государственных структур; на их месте воцаряется стихия хаоса, беспредельного господства силы в самых грубых и варварских формах. 
«Право сильного» получает абсолютное значение в той форме, в которой некогда галльский вождь Бренн впервые дал его классическую формулировку: «Наше право мы носим на конце нашего меча». Оно интериоризируется Европой в своих наиболее простых, брутальных формах. Как следствие, его неизбежным эпилогом звучит сакраментальное «Горе побежденным!» Раннее Средневековье - «темные века». Этот образ дает глубокую и точную характеристику: свет античной цивилизации погас, и Европа погрузилась во тьму, ставшую закономерным финалом того количественного и качественного упадка и регресса, которые наметились в поздней Античности. В ходе варварских нашествий эпохи Великого переселения быстро сокращается численность населения: люди погибают в военных столкновениях, становятся жертвами грабежей и бесчинств. Наступает период социальной анархии и дезинтеграции: распадаются социальные структуры, разрушаются города, храмы и памятники, опустошаются сады и поля, угоняется скот.

В мире, свободном от социальных, моральных, религиозных, правовых норм и запретов, открывается дорога самым диким, разнузданным инстинктам, безудержному насилию и деспотизму, рождается особый, крайне опасный вариант тотальной свободы. Аишенная своего социального и культурного основания, всех норм, условностей, регламентаций, она превращается в черную дыру, в которую моментально проваливается все созданное, наработанное, усвоенное за тысячелетия человеческой истории. «Война всех против всех», стихия уничтожения поглощает культурные универсалии, находя главных адептов среди сильных мира сего.

Аксиология насилия вырастает из мортальных доминант, сопрягая прекрасное и героическое с пафосом уничтожения. Как доказательство - поучения матери своему сыну, варварскому королю, донесенные до нас хронистом VII в. Фредегаром: «Если хочешь стать на путь подвига и прославить свое имя, разрушай все, что другие построили, и уничтожай всех, кого победишь... нет подвига белее прекрасного для обретения славного имени» (цит. по: Ае Гофф, 1992: 22). Именно через искус свободы как разрушения проходят народы и цивилизации на крутых виражах своего исторического развития, во времена революций, смут, восстаний, других масштабных социальных катаклизмов. В опасные периоды перехода именно этот пласт дикости и регресса вдруг вырывается наружу из глубин «коллективного бессознательного» (К. Г. Юнг).

\section{СВОБОАА КАК ПРЕРОГАТИВА ЦЕРКВИ: СРЕАНЕВЕКОВЬЕ}

Пройдя этот этап, средневековый мир коренным образом трансформируется: европейская цивилизация теперь - это замкнутые мирки людей, существующие среди девственной природы, - «люди, живущие на лесных прогалинах» (М. Блок). Большинство населения балансирует на грани выживания, жизнь страшно хрупка. «Война, голод, болезни и звери как четыре меча неистовствуют во всем мире...» - писал современник. Равенство шансов жизни и смерти по-новому определяет пространство свободы: главной становится витальная перспектива, противостоящая смерти. В повседневной борьбе за выживание социальный и природный векторы свободы тесно переплетались: социальная дискриминация бедствий была естественной для средневекового мира.

Поляризация свободы и социальной зависимости в Средневековье не столь велика, как в Античности, тем не менее она носит четко выраженный сословный характер. Та или иная степень несвободы характерна для всех категорий крестьян - личная, поземельная, судебная зависимость определяет их правовое и хозяйственное положение. Унизительные повинности, подчеркивающие статус крестьянина, в том числе мен- 
морт, формарьяж, имели смысл не только экономических, но и моральных санкций. Сословно детерминированная этика давала идейное обоснование психологии насилия, возводя вседозволенность и самодурство сеньора в ранг закона, рассматривая работающего на земле человека как неполноценного, некое подобие скота, морально и физически уродливого.

Иной комплекс социальных свобод, монополизируемый «верхами», демонстрирует европейское рыцарство. Оно консолидируется системой личных связей, лучеобразным строением феодального общества (Карсавин, 1995): иерархическая зависимость одних феодалов от других, вассалов от сеньора не лишала вассала личной свободы и достоинства. «Оазисом» свободы можно также назвать другой феномен средневекового мира - город, создавший особое сословие горожан: «городской воздух делает свободным». Городская община, коммуна создала систему правовой унификации - этот принцип бросает вызов всей иерархии феодального мира. «Коммуна - это отвратительное слово» - так выразил неприязнь к ней в своей знаменитой фразе церковный хронист Гвиберт Ножанский.

Важнейшим фактором онтологизации свободы являлось наличие христианства. Церковь учила, просвещала и наставляла, она же обладала и юридической властью священники наделялись функцией «цензоров повседневной жизни верующих»: они должны были руководить, запрещать, судить, наказывать, прощать (Поньон, 1999: 144-145). Все люди грешны, ни добрые дела, ни достойное поведение не могут принести успокоительной уверенности - так многие века церковь воспитывает верующих в страхе Божием, утверждая в них мысль о собственной греховности. «Средневековье было по преимуществу временем великих страхов и великих покаяний - коллектив-

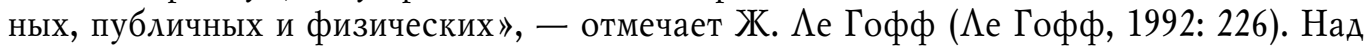
людьми довлела боязнь греха, смерти, посмертного суда, вечного проклятия.

Противоядием от страхов являлся праздник, карнавал, народная смеховая культура. Ее значение в Средние века и в эпоху Возрождения, отмечал М. Бахтин, были огромными. «Праздничность здесь становилась формой второй жизни народа, вступавшего временно в утопическое царство всеобщнсти, свободы, равенства и изобилия» (Бахтин, 1990: 140). Свобода, даруемая смехом, противостояла угнетению, запретам, насилию, ограничениям. Она была, конечно, относительной: ограниченная временнь'ми рамками праздника, она представляла для народа, по определению М. Бахтина, «праздничную роскошь». «Смеющееся народное средневековье» в форме площадных праздников и смеховых обрядов, карнавализованных мираклей и моралите, фольклора и пародийной литературы передает эстафету Ренессансу, но затем постепенно затухает.

Эпоха Возрождения коренным образом изменила культурные ландшафты окружающего мира, существенным образом преобразовав средневековую свободу. Возникает новая мировоззренческая парадигма, светское видение мира, ренессансная культура - гуманизм, в центре которого находится культ человека, признание его достоинства, ренессансный индивидуализм. В контексте новых взглядов «реабилитируется» повседневная человеческая жизнь, расширяя тем самым пространство свободы: презрению к миру и средневековой аскезе Ренессанс противопоставляет античный эпикуреизм, этику наслаждения, преклонение перед красотой человеческого тела. Свобода не только в повседневном, но и в духовном, интеллектуальном, научном плане ставится в повестку дня. Но каждый шаг, раздвигавший ее границы, требовал неимоверных усилий, подвижничества, как свидетельствуют об этом имена Ажордано Бруно, Галилео Галилея, Мигеля Сервета. 
Свобода, связанная с искусством, наукой, интеллектуальным творчеством, была еще робка и несамостоятельна, нуждалась в покровительстве сильных мира сего, потому была сосредоточена в университетах, при дворах европейских монархов. Гуманистическая направленность, ориентированная на античные образцы, утвердилась в Италии. Именно в данном контексте зарождаются европейские этикетные нормы, игравшие в дальнейшем исключительно важную роль в дворянском, позднее в светском обиходе. Этикет жестко ограничивает поведенческий волюнтаризм - свобода индивидуальных проявлений приносится в жертву сословно-иерархическим требованиям: кастовость этикетной нормы призвана была выделять привилегированные сословья, дистанцировать их от простонародья.

Светская культура, ренессансный гуманизм соседствовали с самыми темными и мрачными сторонами жизни, получившими небывалый размах. «Средневековье заканчивается трагическими интонациями, драматической жестикуляцией, неотступным напоминанием о боли, страданиях, тлении плоти», — писал Ж. Аюби (Аюби, 1994: 294). Позднее Средневековье - время великих эпидемий чумы, серьезных демографических кризисов, политических, религиозных, династических войн. Тема смерти приобретает пронзительное звучание, формируется культура макабра, вбирающая в себя мортальный архетип - идеи, образы, ритуалы: смерть стала «спутницей Ренессанса» (Ж. Аелюмо). Танец смерти и Триумф смерти символизируют эту эпоху так же, как гуманизм или расцвет искусства.

Создается инквизиция, специальный орган католической церкви, призванный вести розыск и карать еретиков. Отныне еретиков, ведьм и колдунов приговаривают к сожжению на костре. Но не только их - клеймо еретика может получить человек любого ранга, сословия, национальности: практика пыточного дознания достигает своего полного завершения, она распространяется на все население. Изобретаются и каталогизируются орудия пыток, формализуется теория пыточного процесса - смысл и логика борьбы с ересью отходят на задний план перед автоматизмом действия чудовищного карательного механизма, существовавшего вплоть до середины XIX в. Созданная для контроля над религиозной мыслью и культом, инквизиция превратилась в машину тотального насилия, стала предвестником репрессивных тоталитарных практик XX в.

XVI в. - эпоха Реформации, возникновения протестантизма, выражающего интересы и ценности нарождающейся буржуазии. Идея абсолютного предопределения, закрепленная в идеологеме протестантизма, упраздняет принцип свободы воли, минимизирует любые возможности свободного самоопределения верующих. Моральные нормы и поведение протестантов отличались особой строгостью и аскетизмом мирской суетой и грехом объявлялись развлечения, танцы, музыка, искусства. В темной простой одежде, с оружием или с молитвенником, поющие псалмы, истово верящие в свое дело и предназначение, - такими были английские пуритане, французские гугеноты, немецкие лютеране и кальвинисты. Похожа на них в своем ригоризме и ранняя итальянская буржуазия, последователи Савонаролы, сжигавшие «суету» сего мира на кострах (в том числе произведения Аанте, Боккаччо, Петрарки).

\section{ФОРМИРОВАНИЕ ГРАЖААНСКИХ СВОБОА: НОВОЕ ВРЕМЯ}

Новое время знаменует новый этап европейской свободы. Он связан с Просвещением с его рационализмом, с ярко выраженной антифеодальной, антиклерикальной направленностью - идеология Просвещения создавала пространство для интеллек- 
туальной свободы. Широкое распространение получили идеи Вольтера и Руссо, французских энциклопедистов: разум и воспитание должны совершенствовать человека, способствовать достижению общественного прогресса. Блистательный век Просвещения, будучи интеллектуально-утопическим проектом эпохи, демонстрировал, однако, лишь одну сторону медали. Аругой стороной являлся абсолютизм: неограниченная монархическая власть, концентрировавшаяся в одних руках, противопоставляла всевластие государя абсолютной зависимости его подданных. Аля дворянства и аристократии, отделенных от прочего населения своим господствующим положением, привилегиями и сословной моралью, зависимость принимала форму безусловного подчинения нормам придворного ритуала, этикета, требовала специфических форм поведения. Аух свободы более всего находит свое выражение в галантном обиходе. Свобода нравов, вседозволенность галантного века, характерная для аристократических кругов, делается предметом подражания буржуазии.

Идеи просветителей и философов, оптимизм Просвещения не могли достичь основной массы народа, как недоступно для него было само понятие свободы. В Восточной и Центральной Европе имело место «второе издание крепостничества»: в Прибалтике, Восточной Германии, Австрийской империи, Речи Посполитой усиливается власть владельца над крестьянином, распространяются самые тяжелые формы зависимости - «народ жалок и угнетен тяжелым рабством». Ааже в тех странах, где личная крепостная зависимость была ликвидирована к XIV-XV вв., остались разнообразные натуральные и денежные повинности, сохранялась судебная власть сеньоров над местным населением. Так, только после падения Бастилии революционное Учредительное собрание Франции в своем декрете «Об уничтожении феодальных прав и привилегий» 1789 г. ликвидировало личные повинности крестьян.

Трагично положение низов. Процессы первоначального накопления капитала разрушили средневековую структуру общества, вызвав массовую пауперизацию: масса людей лишается источника существования, рвутся социальные связи, по дорогам бредут голодные и оборванные толпы, ища прибежища и пропитания. Начиная с XIV в. против нищенства и бродяжничества принимаются репрессивные меры, жестокость которых с течением времени возрастает - людей порют плетьми, клеймят раскаленным железом, при рецидивах отправляют на каторгу, вешают (пример - «кровавое законодательство» в Англии). Власти преподают им первые уроки казарменной дисциплины труда. Бродяг повсюду в Европе насильственно лишают свободы, помещают в закрытые заведения, являющиеся неким гибридом тюрьмы и каторги: в Англии работные дома, в Германии - исправительные, во Франции - смирительные. «...Рабство, крепостничество, состояние [наемного] рабочего, - бесконечно напоминают о цепях. То, что цепи были не одни и те же, мало что меняло. Как только упраздняли одно рабство, возникало другое» (Бродель, 1988: 520).

Эпоха абсолютизма знаменует собой подъем и возвышение буржуазии, готовящей свой приход к власти. Основной прорыв в расширении свобод достигается в ходе буржуазных революций. Момент совершения революции - момент абсолютной свободы. Рушатся институты и институции, рвутся связи, скрепляющие социальный организм, отвергаются мораль и право гибнущего мира. Гуманизму нет места в социальном катаклизме, там воцаряется «революционная мораль», оправдывающая любые жестокости «революционной необходимостью»: революция «пожирает своих детей». Когда жизнь снова входит в спокойное русло, те, кто выжил, начинают осваивать пространство новой свободы в ином, изменившемся мире. 
В ходе революционных преобразований диквидируются сословные барьеры, утверждаются социальные и политические права. Свое хрестоматийное выражение новые европейские идеи находят в знаменитом лозунге Великой французской революции: «Свобода, равенство, братство». Их базисом является фундаментальная ценность буржуазного мира - собственность. Так, Учредительное собрание во Франции, приняв Аекларацию прав человека и гражданина, провозгласило свободу, равенство, неприкосновенность частной собственности. Именно осуществленная на практике идея неприкосновенности частной собственности лежит в основе таких институтов, как гражданское общество, правовое государство. Она закладывает фундамент современной западной цивилизации, скрепляет комплекс правовых гарантий, формирующих свободы западного мира.

\section{ЗАКАЮЧЕНИЕ}

В статье представлен процесс формирования самого феномена свободы в смысле, привычном современному обществу, где свобода понимается как в политическом смысле, так и в духовном, будучи опосредованной кантовской телеологией. Показано, что процесс формирования такого феномена, как свобода, достаточно сложен, а история развития - длительна. В современном понимании понятие «свобода» оформилось в границах классической эпохи, эпохи Просвещения и было впервые сформулировано в Аекларации прав человека и гражданина.

На всем протяжении истории свобода неизменно сопровождает человечество: многодикая и многогранная свобода является одним из важнейших онтологических оснований антропогенеза. Ее семантика варьируется в зависимости от ракурса рассмотрения, предлагая в словарях и энциклопедиях различные дефиниции. Аичная независимость или осознанная необходимость; отсутствие гнета и угнетения; возможность выбора; самоволие и самостийность; политико-правовая автономия, оформленная законом или закрепленная традицией, - все эти определения характеризуют ее разнообразные смыслы, принадлежа одному и тому же референтному полю. Очевидно, в той или иной степени в анализе должны быть задействованы все семантические коды.

\section{СПИСОК АИТЕРАТУРЫ}

Аристотель (1983) Сочинения : в 4 т. М. : Мысль. Т. 4.830 с.

Бахтин, М. М. (1990) Творчество Франсуа Рабле и народная культура средневековья и Ренессанса. М. : Художественная литература. 545 с.

Бродель, Ф. (1988) Материальная цивилизация, экономика и капитализм XV-XVIII вв. М. : Прогресс. Т. 2. Игры обмена. 672 с.

Аюби, Ж. (1994) Европа в средние века. Смоленск : Полиграмма. 316 с.

Карсавин, $\Lambda$. П. (1995). Культура средних веков. Киев : Символ; Airland. 208 с.

$\Lambda$ е Гофф, Ж. (1992) Цивилизация средневекового Запада / пер. с фр., общ. ред. Ю. $\Lambda$. Бессмертного. М. : Издательская группа Прогресс ; Прогресс-Академия. 376 с.

Иотман, Ю. М. (2000) Семиосфера. СПб. : Искусство-СПб. 704 с.

Поньон, Э. (1999) Повседневная жизнь Европы в тысячном году / пер. с фр., коммент. Э. М. Арайтовой. М. : Молодая гвардия. 382 с.

Энгельс, Ф. (1961) Анти-Аюринг // Маркс, К., Энгельс, Ф. Сочинения : в 20 т. 2-е изд. М. : Государственное издательство политической литературы. Т. 20.858 с. С. 5-342. 


\section{FREEDOM AS A PHENOMENON OF THE EUROPEAN HISTORY AND ITS MODERN APOLOGY \\ M. I. KOZYAKOVA \\ SHCHEPKIN HIGHER THEATRE SCHOOL}

Among the universal values of human life that hold trues in the modern fast changing world the phenomenon of freedom occupies a special place. The article analyses the phenomenon of European freedom, its foundations, evolution, and transformations which it has undergone during various periods of the European history. It is shown that throughout history freedom invariably accompanies mankind: multifaceted and multilateral freedom is one of the major ontological foundations of anthropogenesis. Its semantics varies depending on the perspective, proposing various definitions in dictionaries and encyclopedias. Personal independence or conscious necessity; lack of burden and oppression; opportunity to chose; self-will and separatism; political and legal autonomy established by law or enshrined in tradition - all these definitions characterize its various meanings, belonging to the same reference field. It is obvious that all the semantic codes should be involved in the analysis to some extent. The article follows the process of the formation of the freedom phenomenon in the sense familiar to modern society where freedom is understood both in the political and in spiritual sense, being mediated Kant's teleology. The author shows that the process of formation of such a phenomenon as freedom is rather complicated, and the history of its development is long. In modern understanding the concept of freedom took shape within the borders of the classical era, the age of Enlightenment, and was first formulated in the Declaration of the Rights of Man and of the Citizen.

Keywords: freedom; Declaration of Human Rights; Enlightment; philosophy; history of Europe; West; history of the West

\section{REFERENCES}

Aristotel' (1983) Sochineniia: in 4 vol. Moscow, Mysl'. Vol. 4.830 p. (In Russ.).

Bakhtin, M. M. (1990) Tvorchestvo Fransua Rable i narodnaia kul'tura srednevekov' ia $i$ Renessansa. Moscow, Khudozhestvennaia literatura. 545 p. (In Russ.).

Brodel', F. (1988) Material' naia tsivilizatsiia, ekonomika $i$ kapitalizm XV-XVIII vv. Moscow, Progress. Vol. II. Igry obmena. 672 p. (In Russ.).

Diubi, Zh. (1994) Evropa v srednie veka. Smolensk, Poligramma. 316 p. (In Russ.).

Karsavin, L. P. (1995). Kul'tura srednikb vekov. Kiev, Simvol; Airland. 208 p. (In Russ.).

Le Goff, Zh. (1992) Tsivilizatsiia srednevekovogo Zapada / transl. from Fr., ed. by Iu. L. Bessmertnii. Moscow, Izdatel'skaia gruppa Progress; Progress-Akademiia. 376 p. (In Russ.).

Lotman, Iu. M. (2000) Semiosfera. St. Petersburg, Iskusstvo-SPb. 704 p. (In Russ.).

Pon'on, E. (1999) Povsednevnaia zhizn' Evropy v tysiachnom godu / transl. from Fr. Moscow, Molodaia gvardiia. 382 p. (In Russ.).

Engel's, F. (1961) Anti-Diuring. In: Marks, K. and Engel's, F. Sochineniia : in 20 vol. 2nd ed. Moscow, Gosudarstvennoe izdatel'stvo politicheskoi literatury. Vol. 20. 858 p. Pp. 5-342. (In Russ.).

Submission date: 12.01.2019.

Козьякова Мария Ивановна - доктор философских наук, профессор, профессор кафедры философии и культурологии Высшего театрального училища (института) имени М. С. Щепкина при Государственном академическом Малом театре России. Адрес: 109012, Россия, г. Москва, ул. Неглинная, д. 6/2. Тел.: +7 (916) 347-79-73. Эл. алрес: markoz@yandex.ru

Kozyakova Maria Ivanovna, Doctor of Philosophy, Professor, Professor, Department of Philosophy and Cultural Science, Shchepkin Higher Theatre School (Institute), State Academic Maly Theatre of Russia. Postal address: 6/2, Neglinnaya, St., Moscow, Russian Federation, 109012. Tel.: +7 (916) 347-79-73. E-mail: markoz@yandex.ru 